\title{
ТВОРЧО-ОСОБИСТІСНИЙ ПІДХІД ДО ОРГАНІЗАЦІЇ САМОСТІЙНОЇ РОБОТИ ПІДЛІТКІВ У ПРОЦЕСІ ФОРТЕПІАННОГО НАВЧАННЯ
}

\author{
У Цзяньцінь \\ аспірантка факультету мистецтв імені Анатолія Авдієвського \\ Національного педагогічного університету імені М.П. Драгоманова, \\ м. Київ, Україна
}

Анотація. У статті розкрито особливості використання творчо-особистісного підходу до організації самостійної роботи підлітків у процесі фортепіанного навчання. Ураховані великі можливості творчо-особистісного підходу, що полягають у створенні перспектив планування підлітком цілеспрямованих способів дій, реалізації його потенційних можливостей. Виокремлена доцільність використання творчо-особистісного підходу на практичних фортепіанних заняттях із підлітками. Визначено значення самостійності в навчанні підлітків гри на фортепіано, що дозволяє синтезувати вміння учнів без сторонньої допомоги зорієнтуватися в незнайомому музичному матеріалі, скласти переконливу інтерпретацію музичного твору, віднайти ефективні шляхи роботи, необхідні прийоми та засоби втілення художнього задуму і здатність критично оцінити результати власної музично-виконавської діяльності.

Ключові слова: творчо-особистісний підхід; організація самостійної роботи підлітків; фортепіанне навчання; самостійність; утілення художнього образу.

Постановка проблеми в загальному вигляді. Специфіка творчоособистісного підходу полягає в тому, що процес конструювання і реалізації музично-педагогічної діяльності орієнтується на особистість як мету, суб'єкт та ефективний результат. Цей підхід характеризує особистість як унікальне явище, що передбачає створення відповідних умов для природного процесу саморозвитку та самореалізації в становленні творчого потенціалу суб'єкта мистецької освіти.

Аналіз останніх досліджень і публікацій. Значення творчо-особистісного підходу в регуляції навчальної діяльності учнів підкреслювали I. Бех, В. Володько, Н. Гребенюк, Т. Гуменнікова, О. Олексюк, В. Орлов, М. Чобітько, В. Шульгіна та ін. Запровадження творчо-особистісного підходу до навчання, розробленого теоретиками i практиками мистецької освіти Г. Падалкою, О. Пєхотою, О. Рудницькою та ін., дозволяє особистісно-суб'єктний досвід підлітків у сфері музичного мистецтва наблизити до його практичного використання. Такий підхід до вивчення навчального матеріалу дозволяє призвести особистісний досвід учнів відповідно до змісту мистецького навчання.

Формулювання цілей статті. Метою статті $\epsilon$ розкриття основних тенденцій музичного навчання підлітків на засадах творчо-особистісного підходу. 3 цієї позиції важливо виокремити значення самостійності в навчанні підлітків гри на фортепіано, що дозволяє синтезувати їхнє вміння без сторонньої допомоги та зорієнтуватися в незнайомому музичному матеріалі, самостійно набувати вміння й навички. 
Результати дослідження. Важливим аспектом творчо-особистісного підходу до музичного навчання є формування важливих якостей і практичносамостійних навичок підлітків, що сприяють їхній саморегуляції, самоорганізації та самореалізації в процесі практичної діяльності, що спонукає учнів до активної роботи. Сучасні вчені (І. Бех, В. Володько, Г. Падалка, О. Пехота, О. Рудницька та ін.) схиляються до думки, що творчо-особистісний підхід - це не просто облік індивідуальних особливостей учнів, а насамперед визначення шляхів становлення їхньої продуктивної діяльності.

3 цієї позиції К. Абульханова-Славська стверджує, що творчо-особистісний підхід дозволяє розкрити особливі якості психічної діяльності учнів, «вищий рівень здійснення регулювання їхньої активності, що сприяє ініціюванню та реалізації власних стратегічних планів [1, с. 133]. Сутність творчо-особистісного підходу полягає у створенні перспектив планування суб'єктом цілеспрямованих способів дій, реалізації потенційних можливостей, що сприяє безперервному розвитку. Це дає підставу стверджувати, що чим успішніше відбувається розвиток значущих особистісних якостей учнів, тим краще засвоюються ними музичні знання, уміння й навички, у результаті чого ефективніше відбувається злиття всіх складових музичної діяльності підлітків.

Творчо-особистісний підхід до розвитку самостійності учнів у сфері музичної освіти передбачає перевагу: усвідомлену установку в процесі власного тлумачення, пояснення, розуміння художнього образу музичних творів; бажання зрозуміти сутність засобів музичної виразності; зосередження уваги на специфіці музичної мови; розуміння глибокого смислу мистецьких творів через багатоаспектний аналіз виражальних засобів; залежності значення будь-яких мистецьких подій або явищ від контексту, сукупності актуальних і потенційних зв'язків.

3 позиції розкриття творчо-особистісного підходу в процесі навчальної діяльності актуальними постають філософські погляди Г. Сковороди про самопізнання особистістю «сродних нахилів і здібностей», праці за покликанням; про самореалізацію, яка передбачає самовдосконалення особистості, розвиток творчих здібностей, закладених природою. Учений наполягав на тому, що особистості необхідно «дослухатись до себе», відчути, не зігнорувати потяг до «милого серцю» роду діяльності, реалізувати творчий потенціал, закладений природою, що й визначає феномен природної «сродності» до певного виду творчої діяльності [6, с. 386].

Особливо доцільно використовувати творчо-особистісний підхід на практичних фортепіанних заняттях 3 учнями як однієї 3 основних форм навчальної роботи, що готує учнів до практично-виконавської діяльності, де мають використовуватись різні методи: перевірка виконання самостійно підготовлених завдань, з'ясування характеру творів, що вивчаються, показ нових інструментальних прийомів, рекомендації щодо опанування новими завданнями та аналіз джерел отримання додаткової інформації, співвідношення яких може 
змінюватися залежно від конкретної мети кожного завдання. Ефективність цієї роботи суттєво зростає за умов застосування діалогічних методів навчання, обміну думок, створення можливості для підлітків висловлювати власні судження й приймати спільні рішення. Отже, використання творчо-особистісного підходу дозволяє підліткам здобувати вміння самостійної роботи.

На думку П. Підкасистого, самостійна робота учнів - це «різноманіття типів навчальних, виробничих і дослідницьких завдань, що виконуються під керівництвом учителя, для засвоєння різних знань, набуття навичок i вмінь, досвіду творчої діяльності та вироблення власної системи поведінки» [5, с. 38]. Учений також уважає самостійну роботу учнів важливим засобом навчання, що в кожній конкретній ситуації дозволяє таким чином засвоювати знання, щоб вони відповідали конкретній дидактичній меті та завданню; є необхідною умовою самоорганізації і самодисципліни того, хто навчається в оволодінні методами пізнавальної діяльності; дозволяє учням виробити психологічну установку на самостійне систематичне поповнення своїх знань і вироблення вмінь орієнтуватися в потоці наукової та іншої інформації при вирішенні нових пізнавальних завдань; є найважливішим знаряддям педагогічного керівництва i управління самостійною пізнавальною діяльністю учнів у процесі навчання [5, с. 149]. Важливо підкреслити те, що ефективна самостійна робота стає засобом активної пізнавальної діяльності учнів за певних умов, якщо чітко поставлена мета роботи; учні усвідомлюють і приймають цю мету; у процесі роботи учні долають інтелектуальні труднощі, проявляючи вольові зусилля; під час роботи закріплюються або отримуються нові знання і способи діяльності; у процесі виконання роботи учень розвиває свої здібності.

Самостійна робота учнів, на думку І. Зимньої, є наслідком правильно організованої навчальної діяльності на уроці, що мотивує самостійне іiі розширення, поглиблення і продовження у вільний час. Для вчителя це означає не лише чітке усвідомлення власного плану навчальних дій, а й усвідомлене його формування в учнів як певної схеми освоєння навчального предмета в ході вирішення нових навчальних завдань. Але загалом це паралельно наявна зайнятість школяра $з$ обраних ним готових програм або виробленої ним самим програми засвоєння будь-якого матеріалу. При цьому самостійна робота - це вища форма навчально-пізнавальної діяльності учнів, основна форма самоосвіти, що щільно пов’язана з його роботою в класі [3, с. 249].

Проте, на думку вчених (І. Бех, В. Володько, О. Сременко, Г. Падалка, О. Пєхота, О. Рудницька та ін.), самостійна робота - це такий вид діяльності, що виконується без безпосередньої участі вчителя, але за його завданням у спеціально відведений для цього час, при цьому учні свідомо прагнуть досягти поставленої мети, використовуючи свої зусилля і виражаючи в тій чи тій формі результат розумових або фізичних (або тих й інших разом) дій. Саме самостійна робота дозволяє виробити високу культуру розумової праці, формує в учнів потребу в самостійній діяльності, прагнення вникнути в суть питання, йти в глиб 
ще невирішених проблем. У процесі такої праці найбільш повно виявляються індивідуальні здібності школярів, їхні нахили та інтереси, які сприяють розвитку вміння аналізувати факти та явища, учать самостійності мислення, яке призводить до творчого розвитку та створення власної думки, своїх поглядів, уявлень, своєї позиції.

Велике значення надавав самостійній роботі учнів І. Зязюн. Він визначив науково обгрунтовані аргументи щодо самостійної діяльності учнів: сама собою нова інформація не затримується в пам'яті в тій самій формі, у якій вона подавалась, а поєднується 3 уже відомим, накладається на отриманий досвід: психологічні особливості навчання. Через це найкращий результат отримується в результаті самостійного пошуку, досліджень; у процесі навчання кожен має свій «стиль» навчання - спосіб сприйняття та запам'ятовування інформації, власний досвід, своя манера вчитись; через це більш дієвим буде індивідуалізований процес навчання, де учень, спираючись на поради вчителя, самостійно знаходить правильні відповіді та здобуває корисні знання; постійна зміна та приріст великого об’єму інформації вимагає від кожного активно сприймати, відбирати та засвоювати дійсно важливі факти. Виконання завдання без безпосередньої допомоги вчителя не означає відсутності його керівної ролі. При організації самостійної роботи роль учителя не знижується, а, навпаки, підвищується [4, c. 23]. Тому рівень самостійності, на думку I. Зязюна, не пов’язаний із часовим фактором. Діяльність особистості може кваліфікуватись самостійною незалежно від часу проходження. Ця різниця є суттєвою і слугує основою для розподілу активності й самостійності суб'єктів учіння як окремих дидактичних принципів, на яких грунтується самоучіння.

Доречно зазначити, що самостійна робота також є ефективним способом активізації здібностей, потреб, інтересів учнів; показником (критерієм) сформованості вмінь і навичок у різних видах мистецької діяльності; етапом, у межах якого підліток готовий до самоосвіти; самореалізації; умовою особистісного розвитку учня. Позитивним результатом успішно виконаної самостійної роботи є розвиток музичного мислення, пам'яті, уяви, уваги, вольових зусиль тощо; формування предметної (фахової) компетентності.

Отже, результати проведеного аналізу дозволили виявити, що під самостійною роботою учнів слід розуміти таку форму організації власної навчально-пізнавальної діяльності, яка здійснюється опосередковано під керівництвом учителя, у ході якої учні на різних етапах навчання самостійно виконують певні завдання для отримання, поглиблення та закріплення знань, формування певних умінь і навичок на основі творчо-особистісного підходу.

У процесі формування вмінь самостійної роботи важливо навчити підлітка правильно організовувати домашню роботу. Необхідно допомогти учню в складанні денного розкладу, щоб була дотримана розумна послідовність у музичних заняттях. Учні музичних шкіл не можуть приділяти дуже багато часу грі на фортепіано, тому педагог повинен звернути увагу на підвищення якості 
самостійної роботи, привчати з перших років навчання займатися так, щоб жодна хвилина не пропала даремно. Одне 3 найважливіших завдань - раціонально розподіляти свій час між різними видами музичної роботи. Учитель повинен акцентувати увагу на першочергових завданнях, вибудовувати схематичний план самостійної роботи. Організовуючи цю роботу, учитель повинен пам'ятати, що урок - зразок щоденної самостійної роботи вдома.

У процесі фортепіанного навчання слід розвивати дбайливе ставлення підлітка до тексту, переконувати учня, що без точного виконання вказівок композитора не можна домогтися повної передачі авторського задуму. Важливо, щоб учень не лише вмів слухати себе, але й знав, що під час роботи необхідна самостійна перевірка, адже досить часто виникають фальшиві ноти, неточності голосоведення, недоречні зміни темпу тощо. Дуже корисно час від часу вивчати самостійно невеликий твір без допомоги вчителя, що сприяє поліпшенню якості самостійної роботи учнів. 3 найперших кроків юний музикант повинен ділитися 3 навколишніми тим, що придбав у будь-якій формі, яка йому доступна: грати знайомим, рідним, грати на прослуховуваннях і концертах, причому так грати, щоб відчувалася максимальна віддача, відповідальність за якість виконання. Загалом, уміння читати з листа, підбирати, транспонувати, грати в ансамблі, акомпанувати, складати i записувати власні твори сприяють розвитку самостійності учня.

На думку Г. Ципіна, поняття самостійності в навчанні музики є достатньо містким та багатоплановим, воно виявляє себе на різних рівнях, синтезуючи (наприклад, при навчанні грі на музичному інструменті) уміння учня без сторонньої допомоги зорієнтуватися в незнайомому музичному матеріалі, скласти переконливу інтерпретаторську «гіпотезу», і готовність самому віднайти ефективні шляхи роботи, необхідні прийоми та засоби втілення художнього задуму, і здатність критично оцінити результати власної музично-виконавської діяльності [7, с. 169]. Кожному педагогу-музиканту відомо, що результат занять набагато покращується за умови активності учня, яка залежить від нього самого, але іiі прояву сприяють і методика проведення занять, і умови, які створюються вчителем.

Висновки 3 дослідження і перспективи подальших розвідок у цьому напрямі. Найбільш сприятливим грунтом для виховання самостійності учня $\epsilon$ позааудиторна, домашня робота. У процесі цієї роботи підлітку доводиться без сторонньої допомоги аналізувати, зіставляти та узагальнювати явища: активно мислити на основі вже набутого досвіду. В умовах домашньої роботи учень самостійно вивчає нотний текст, аналізує якість звучання, визначає технічні труднощі, тобто глибше пізнає та осмислює свою діяльність, пильніше придивляється до різних явищ і бачить їхні причинні зв'язки.

\section{СПИСОК ВИКОРИСТАНИХ ДЖЕРЕЛ}


1. Абульханова-Славская, К. А. (1980). Деятельность и психология личности. Москва, Россия: Наука.

2. Бех, І. Д. (1998). Особистісно зорієнтоване виховання. Київ, Україна: ІЗМН.

3. Зимняя, И. А. (2001). Педагогическая психология. Москва, Россия: Логос.

4. Зязюн, І. А. (2000). Педагогіка добра: ідеали і реалії. Київ, Україна: МАУП.

5. Пидкасистый, П. И. (1980). Самостоятельная познавательная деятельность школьников в обучении. Москва, Россия: Педагогика.

6. Сковорода, Г. С. (1994). Твори у 2-х томах. Том 1. Київ, Україна

7. Цыпин, Г. М. (1994). Психология музыкальной деятельности: проблемы, суждения, мнения. Москва, Россия: Инрерпракс.

\title{
ТВОРЧЕСКО-ЛИЧНОСТНЫЙ ПОДХОД К ОРГАНИЗАЦИИ САМОСТОЯТЕЛЬНОЙ РАБОТЫ ПОДРОСТКОВ В ПРОЦЕССЕ ФОРТЕПИАННОГО ОБУЧЕНИЯ
}

\author{
У Цзяньцин \\ аспирантка факультета искусств имени Анатолия Авдеевского \\ Национального педагогического университета имени М.П. Драгоманова, \\ г. Киев, Украина
}

Аннотация. В статье раскрыты особенности использования творчески-личностного подхода к организации самостоятельной работы подростков в процессе фортепианного обучения. Учтены большие возможности творчески личностного подхода, заключаются в создании перспектив планирования подростком целенаправленных способов действий, реализации его потенциальных возможностей. Выделена целесообразность использования творчески личностного подхода на практических фортепианных занятиях с подростками. Определено значение самостоятельности в обучении подростков игры на фортепиано, что позволяет синтезировать умения учащихся без посторонней помощи сориентироваться в незнакомом музыкальном материале, составить убедительную интерпретацию музыкального произведения, найти эффективные пути работы, необходимые приемы и средства воплощения художественного замысла и способность критически оценить результаты собственной музыкально исполнительской деятельности.

Ключевые слова: творчески-личностный подход; организация самостоятельной работы подростков; фортепианное обучения; самостоятельность; воплощение художественного образа.

\section{CREATIVE AND PERSONAL APPROACH TO THE ORGANIZATION OF TEENAGERS' INDEPENDENT WORK IN THE PROCESS OF PIANO TRAINING}

\author{
U Jianqing \\ Post-Graduate Student of the Faculty of Arts named after Anatoly Avdiyevsky \\ National Pedagogical Dragomanov University \\ Kyiv, Ukraine
}

Abstract. The article reveals the peculiarities of the use of creative and personal approach to the organization of independent work of teenagers in the process of piano training. The significance of the creative and personal approach in the regulation of students' educational activity is emphasized 


\section{У ЦЗЯНЬЦІНЬ}

Творчо-особистісний підхід до організації самостійної роботи підлітків у процесі фортепіанного навчання

by I. Bekh, N. Hrebeniuk, T. Humennikova, O. Oleksiuk, V. Orlov, M. Chobitko, V. Shulhina and others. The introduction of creativity-personal approach to learning was developed by the scholars of artistic education H. Padalka, O. Pekhota, O. Rudnytska and others.

The great opportunities of creative and personal approach, consisting in creating prospects for planning a teenager purposeful ways of action, the realization of its potential opportunities are considered. The expediency of using the creative and personal approach in piano practical lessons with teenagers is singled out. The significance of autonomy in teaching teenagers in playing the piano, which allows to synthesize the students' ability to orient themselves in unfamiliar music material, to make a convincing interpretation of the musical work, to find the effective ways of work, the necessary techniques and means of embodiment of the artistic design, and the ability to critically evaluate the results of musical and performing activities.

The author concludes that the most favorable ground for the education of student autonomy is extra-curricular activity. In the process of this work, the teenager has to analyze, compare and generalize phenomena without any help: thinking actively on the basis of experience is acquired. In the context of homework, the student independently studies the musical text, analyzes the quality of sound, determines the technical difficulties, that is, more profoundly recognizes and comprehends its activities, more closely observes different phenomena and sees their causal relationships.

Key words: creative and personal approach; organization of independent work of teenagers; piano training; independence; embodiment of artistic image.

\section{REFERENCES (TRANSLATED AND TRANSLITERATED)}

1. Abulkhanova-Slavskaya, K. A. (1980). Activity and personality psychology. Moscow, Russia: Science.

2. Bekh, I. D. (1998). Personality-centered education. Kyiv, Ukraine: IZMN.

3. Zymnyaya, I. A. (2001). Educational psychology. Moscow, Russia: Logos.

4. Ziaziun, I. A. (2000). Pedagogy of the kindness: ideals and realities. Kyiv, Ukraine: MAUP.

5. Pidkasystyi, P. I. (1980). Independent cognitive activity of schoolchildren in training. Moscow, Russia: Pedagogika.

6. Skovoroda, H. S. (1994). Works in 2 volumes. Volume 1. Kyiv, Ukraine.

7. Tsypin, G. M. (1994). Psychology of musical activity: problems, judgments, opinions. Moscow, Russia: Inerpraks.

Матеріали надійшли до редакції 02.12.2018 р. 